\title{
TRIASSIC WOOD FROM THE GORDON VALLEY, CENTRAL TRANSANTARCTIC MOUNTAINS, ANTARCTICA
}

by

\author{
Georgina M. Del Fueyo ${ }^{1}$, Edith L. Taylor ${ }^{2}$, Thomas N. Taylor ${ }^{2} \&$ \\ N. Rubén Cúneo ${ }^{3}$
}

\begin{abstract}
SUMMARY
Wood from an in situ permineralized forest from the Middle Triassic of Gordon Valley (Queen Alexandra Range, central Transantarctic Mountains) in Antarctica is described as a new taxon. Approximately 100 trunks in growth position are present at the site; they range from 13-61 $\mathrm{cm}$ in diameter and suggest that some of the trees were up to $20 \mathrm{~m}$ tall. Pits in the radial walls of the tracheids are of the abietinean type. Rays are uniseriate and 1-9 cells high; cross fields include one to two pits that appear to be simple. Axial parenchyma is absent. Pith and cortex are not preserved. The Antarctic wood is compared with existing fossil wood types from Antarctica and other parts of Gondwana. Although the fossil wood shares a number of characteristics with the Podocarpaceae, it differs from any existing genera and is described as a new taxon, Jeffersonioxylon gordonense.
\end{abstract}

Key words: Petrified forest, anatomy, Triassic, Antarctica, Podocarpaceae, wood, gymnosperms.

\section{INTRODUCTION}

Petrified gymnosperm woods from the southern hemisphere are common in strata ranging from the late Paleozoic to the Tertiary. Numerous taxa have been described from Triassic rocks in all parts of Gondwana, including India (e.g., Sahni 1931), South Africa (e.g., Kräusel 1949; Giraud \& Hankel 1986), Argentina (e.g., Bonetti 1966), New Caledonia (e.g, Lanteaume 1950; Salard 1968), Madagascar (e.g., Loubière 1938), Australia (e.g., Shirley 1898; Burges 1935), and New Zealand (Stopes 1916).

Historical collections of fossil wood represented some of the earliest evidence of past life in Antarctica. Specimens were collected on expeditions as early as the turn of the century (e.g., Sharman \& Newton 1894, 1898; Gothan 1908). Mesozoic wood has been reported from both the continent (e.g., Grindley et al. 1964; Barrett et al. 1986; Tessensohn and Mädler 1987) and the peninsula region (e.g., Halle 1912; Douglas

1) Museo de Ciencias Naturales de Buenos Aires, Av. A. Gallardo 470, Buenos Aires, Argentina.

2) Address for correspondence: Byrd Polar Research Center and Department of Geological Sciences, The Ohio State University, Columbus, OH 43210, U.S.A.

3) Museo Paleontológico, 955 Av. 9 de Julio, Trelew, Chubut, Argentina. 
1923). Many of these papers, however, are geological reports that only mention the occurrence of petrified wood samples and do not include detailed anatomical or systematic descriptions. Gordon (1930) described Dadoxylon (Araucarioxylon) from South Georgia (Antarctic peninsula region) and Seward (1914) detailed Antarcticoxylon priestleyi from the Priestley Glacier area (northern Victoria Land). However, neither of these specimens can be accurately dated. Gordon's specimen was collected on a beach and was assigned to either the upper Paleozoic or lower Mesozoic. Although Walton (1925) later included A. priestleyi in the Triassic genus Rhexoxylon, Seward's material was collected from a moraine and the exact age is therefore uncertain. It may have originated in Triassic, Jurassic, or even Permian rocks (Skinner \& Ricker 1968). There are several examples of Cretaceous gymnospermous wood (e.g., Jefferson \& MacDonald 1981; Torres \& Lemoigne 1989; Chapman \& Smellie 1992; Francis \& Coffin 1992; Philippe et al. 1993), including wood with growth rings that have provided paleoclimate information (Francis 1986). Jurassic wood from Antarctica, although relatively rare, has been reported (Jefferson et al. 1983; Tasch \& Gafford 1984).

Although in situ petrified forests, in which the trees are fossilized in growth position, are rare in the southern hemisphere, a few have been reported. Conwentz (1885) described a forest of Oligocene age from Patagonia that consisted of several different wood types (Cupressinoxylon, Glyptostroboxylon, and Araucarioxylon). The Cerro Cuadrado petrified forest of Patagonia (Jurassic) is perhaps the best known in situ fossil forest in Gondwana. The wood of these massive trees was believed to have araucarian, or perhaps taxodiaceous affinities (Wieland 1935; Calder 1953), but Stockey's work on ovulate cones from the same deposit suggested taxodiaceous and pinaceous affinities for Pararaucaria (Stockey 1977). Recently, Cúneo (1991) provided an ecological analysis of the Patagonian forests. Halle (1912) noted a podocarptype fossil forest in the Falkland Islands (Islas Malvinas), which was later examined by Birnie and Roberts (1986) and determined to be Tertiary in age.

Antarctica also has a few records of in situ petrified forests. Perhaps the best known are the Lower Cretaceous forests on Alexander Island (Jefferson 1982). In the central Transantarctic Mountains a small Permian forest was described from Mt. Achernar (Taylor et al. 1992; Cúneo et al. 1993). Perhaps the largest in terms of numbers of in situ individuals is a Triassic site in the Gordon Valley, where there are approximately one hundred trees in growth position (Cúneo et al. 1991). Sedimentological data suggest that this forest grew on the levees of a braided stream system. Based on the spacing of the individuals, diameter of the trees, and number of annual rings (maximum of 86 rings), this forest is interpreted as being mature (Taylor et al. 1991). The sediments in which the trees are rooted contain abundant specimens of the common Triassic leaf type Dicroidium (Corystospermales = Mesozoic seed ferns). However, features of the wood are more typically coniferous (pycnoxylic with few rays) than pteridospermous (manoxylic with many wide rays). Since the Gordon Valley trunks do not appear similar to any other wood types described to date, we have placed them in a new genus. The intent of this paper is to describe the wood from this site and to compare it with other fossil and, where possible, extant woods. 

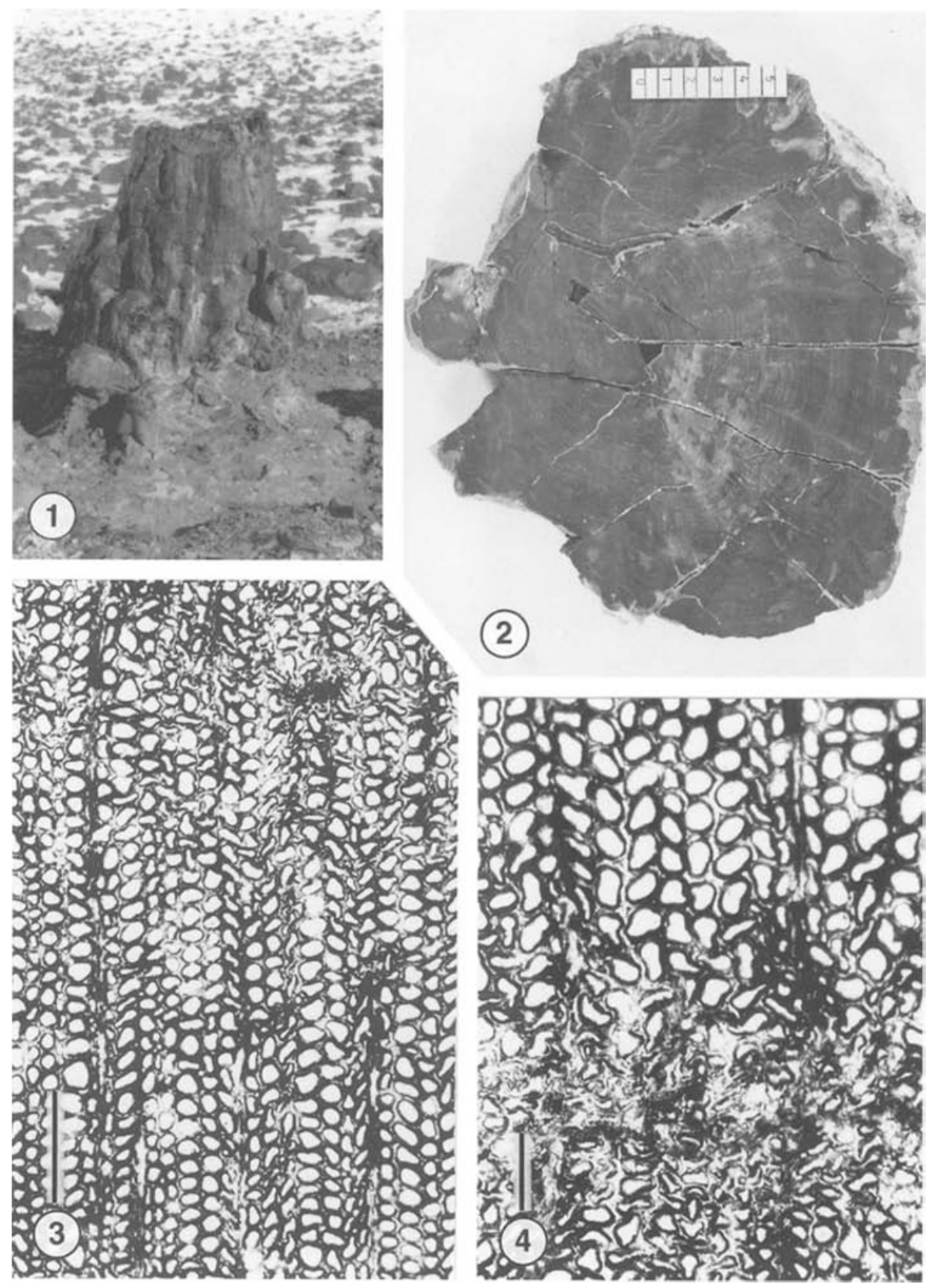

Fig. 1-4. Jeffersonioxylon gordonense. - 1: In situ tree from the Gordon Valley site. Trunk is approximately 0.5 meters tall. -2 : Transverse section of in situ tree showing several growth rings. Specimen No. 11,469 A; scale bar $=5 \mathrm{~cm} .-3$ : Transverse section showing uniseriate rays and distribution of tracheids. Specimen No. 11,471 AB; scale bar $=200 \mu \mathrm{m}$. -4 : Transverse section showing false growth ring with zone of crushed cells. Specimen No. 11,471 AB; scale bar $=100 \mu \mathrm{m}$. 


\section{MATERIALS AND METHODS}

All of the trunks are silicified and preserved in growth position (Fig. 1); in a few specimens it is possible to observe the transition region between the stem and subaerial portions. The site of the forest is a levee deposit in the Gordon Valley $\left(84^{\circ} 11^{\prime} 10^{\prime \prime} \mathrm{S}\right.$, $164^{\circ} 54^{\prime} 28^{\prime \prime} \mathrm{E}$ ), Beardmore Glacier region, central Transantarctic Mountains (Barrett \& Elliot 1973). Stratigraphically, the site is within the Fremouw Formation, which is regarded as Early-Middle Triassic (Barrett et al. 1986).

Cellulose acetate peels of transverse, radial and tangential sections of the main trunks (specimen nos. 11469, 11470, 11471, 11473, 11517, 11618) were prepared by etching the specimens in $49 \%$ hydrofluoric acid for intervals of 10, 20,30, 60 and $120 \mathrm{sec}-$ onds. Varying the etching time was necessary because of the differential preservation within the trunks. A few thin peels were stained with safranin in an attempt to enhance contrast. Peels were mounted on standard microscope slides with Coverbond mounting medium. Slides and peels are deposited in the Paleobotanical Collections of the Ohio State University under the following acquisition numbers: 15,190-15,240.

\section{SYSTEMATICS}

\section{FAMily Podocarpaceae?}

Jeffersonioxylon Del Fueyo, Taylor, Taylor et Cúneo, nov. gen.

Generic diagnosis: Coniferous wood with tracheids polygonal in cross section and fusiform longitudinally; pitting on radial walls uniseriate or biseriate, bordered; pits round with inner aperture elliptical or round; cross-field pitting: 1 or 2 circular to oval pits per field; rays uniseriate and homocellular, 1-9 cells high; axial parenchyma absent.

Jeffersonioxylon gordonense Del Fueyo, Taylor, Taylor et Cúneo, nov. spec.

Specific diagnosis: Trunks up to $60 \mathrm{~cm}$ in diameter with well-developed secondary xylem; tracheids approximately $40 \mu \mathrm{m}$ in diameter and greater than $1200 \mu \mathrm{m}$ long; wall $5 \mu \mathrm{m}$ thick with bordered pits on radial walls in a single row or two opposite rows, pits separated, circular, $10 \mu \mathrm{m}$ in diameter with elliptical to rounded inner aperture; tangential pits generally absent; cross-field pits one or two, circular (5 $\mu \mathrm{m})$ to ovate $(5 \times 3 \mu \mathrm{m})$, and horizontal to obliquely positioned; rays homocellular, uniseriate and 1-9 cells high ( 3 or 4 most common), rays separated by $2-19$ rows of tracheids, parenchyma of rays with thin, unpitted walls ( $2.5 \mu \mathrm{m}$ thick); vertical walls straight to oblique in radial section; ray cells $25 \mu \mathrm{m}$ high by $20 \mu \mathrm{m}$ wide in tangential section and up to $116 \mu \mathrm{m}$ long in radial view.

Holotype: Specimen 11471 A, B. - Paratypes: Specimens 11469 A, B; 11470 A-C; 11473; 11517 A-D; 11618.

Collection locality: Upper Gordon Valley, central Transantarctic Mountains, Antarctica $\left(84^{\circ} 11^{\prime} 10^{\prime \prime} \mathrm{S}, 164^{\circ} 54^{\prime} 28^{\prime \prime} \mathrm{E}\right)$. 
Stratigraphic position: Upper part of the Fremouw Formation, Beacon Supergroup, Middle Triassic.

Etymology: The generic name Jeffersonioxylon is given in honor of the late Timothy Jefferson, who pioneered the study of Antarctic fossil woods and their importance in understanding paleoclimate; the specific name gordonense refers to the Gordon Valley collecting site.

\section{Description}

In all of the trunks studied, only secondary xylem was preserved; the trunks were apparently decorticated during preservation and pith/primary xylem was not preserved. Mean trunk diameter is approximately $25 \mathrm{~cm}$ (range $=20-60 \mathrm{~cm}$ ).

In almost all the sections examined, the individual wood cells are crushed and in some cases extensively distorted (Fig. 4). For example, in Specimen 11,517 there are regions where the wood appears in a zig-zag pattern due to compression of the tracheids. Transverse sections of the trunks exhibit growth rings (Fig. 5), although due to poor preservation, many of these are easier to discern at low magnification (Fig. 2). In addition, extensive crushing of some tracheids gives the appearance, at low magnification, of false rings. Growth rings range from a few tenths of a millimeter up to about 7 millimeters in width. Individual tracheids are tangentially flattened, or compressed so that the cells are sinuous in transverse section. In some regions tissue distortion is so extensive that it is impossible to identify cell walls (Fig. 4). It is probable that the wood distortion is the result of mechanical compaction during diagenesis, perhaps in response to the trees being inundated by muds that subsequently shifted and compacted the trunks. Crushed and compressed bands of cells have been reported in other fossil woods, including those from Antarctica (Kräusel 1962; Maheshwari 1963, 1972).

\section{Legends of Figures 5-15:}

Fig. 5-9. Jeffersonioxylon gordonense. - 5: Transverse section showing growth ring. Arrow indicates region of probable latewood. Specimen No. 11,469 BB; scale bar $=100 \mu \mathrm{m}$. -6 : Transverse section showing distribution of tracheids and rays. Specimen No. 11,471 AB; scale bar $=100 \mu \mathrm{m} .-7$ : Detail showing thick secondary wall of tracheids. Upper arrow indicates region where middle lamella is preserved; lower arrow designates a pit. Specimen No. 11,471 $A B$; scale bar $=25 \mu \mathrm{m}$. -8 : Tangential section of uniseriate ray seven cells high. Note contents in several of the parenchyma cells. Specimen No. 11,471 A; scale bar $=50 \mu \mathrm{m}$. - 9: Tangential section showing bordered pits of two tracheids. Specimen No. 11,471 A; scale bar $=50 \mu \mathrm{m}$.

Fig. 10-15. Jeffersonioxylon gordonense. - 10: Radial section showing ray (arrow). Note uniseriate pits of tracheids. Specimen No. 11,471 BB; scale bar $=100 \mu \mathrm{m}$. -11 : Radial section of ray. Note thin, oblique end walls and dark contents. Specimen No. $11,471 \mathrm{Ba}$; scale bar $=50 \mu \mathrm{m}$. - 12: Radial section showing two possible cross-field pits (arrows), each with a single aperture. Specimen No. 11,471 Ba; scale bar $=25 \mu \mathrm{m}$. -13 : Tracheid showing a single row of bordered pits. Specimen No. 11,471 Ba; scale bar $=50 \mu \mathrm{m}$. -14 : Tracheid with two rows of opposite pits. Specimen No. 11,471 Ba; scale bar $=25 \mu \mathrm{m}$. -15 : Ray cell with three cross-field pits (arrows). Specimen No. 11,471 Ba; scale bar $=25 \mu \mathrm{m}$. 

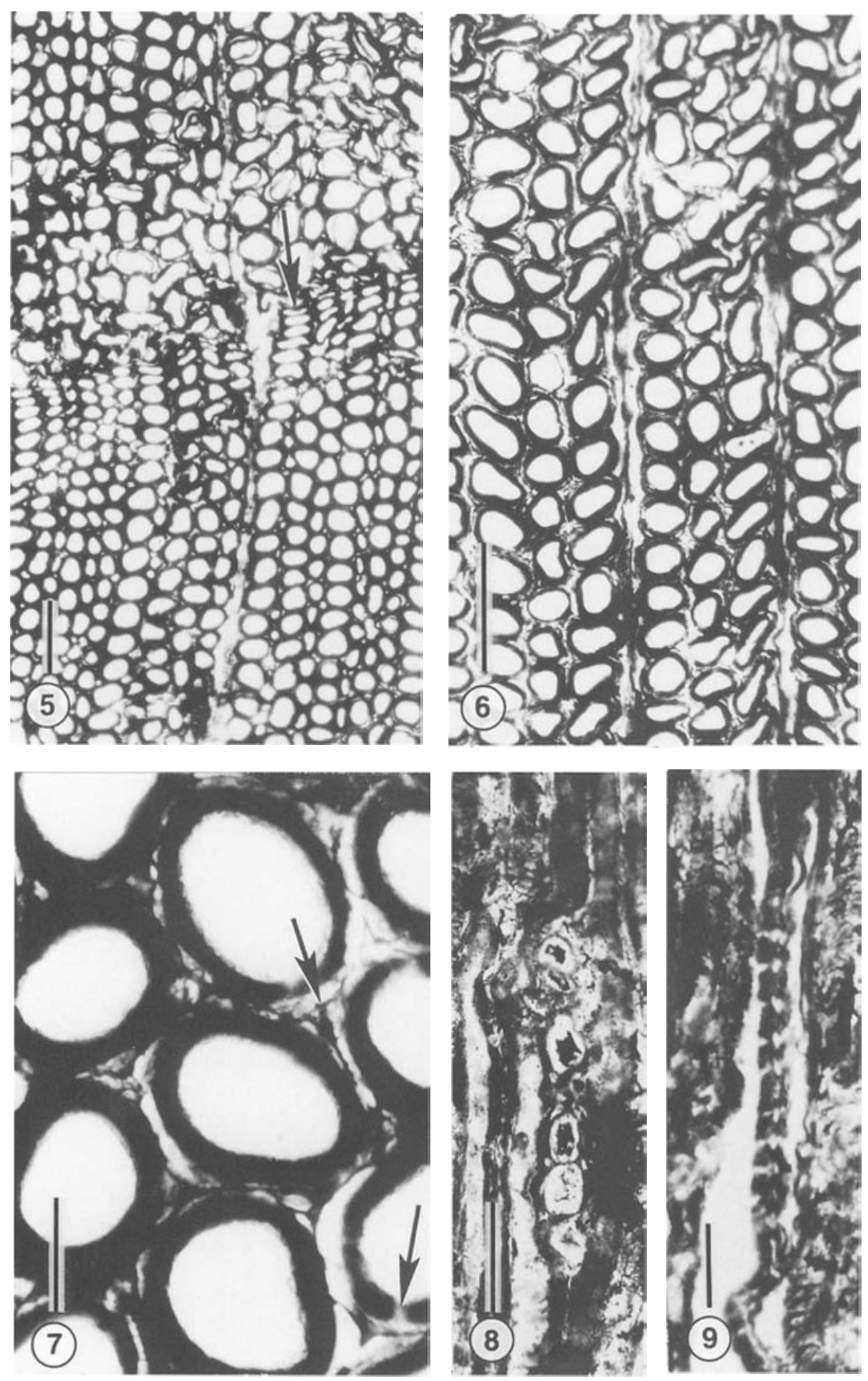


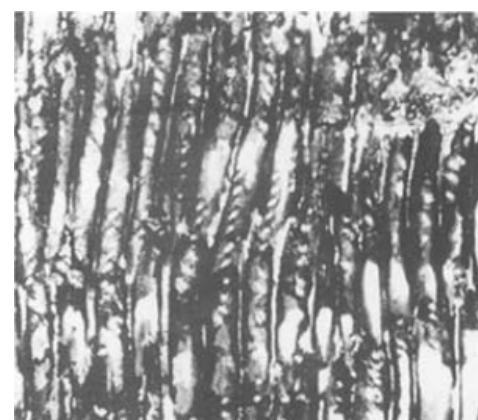

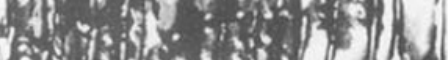
Bil

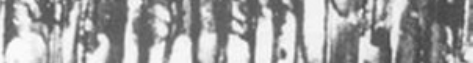
(1) M tal if $\mathrm{N} / \mathrm{fl}$ a A.

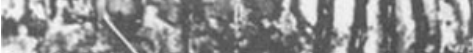
aco 3 . 1030 (0)

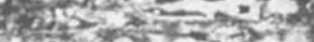

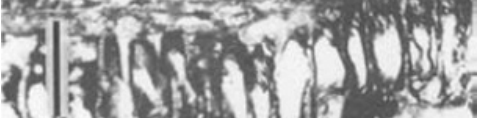

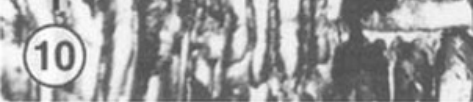
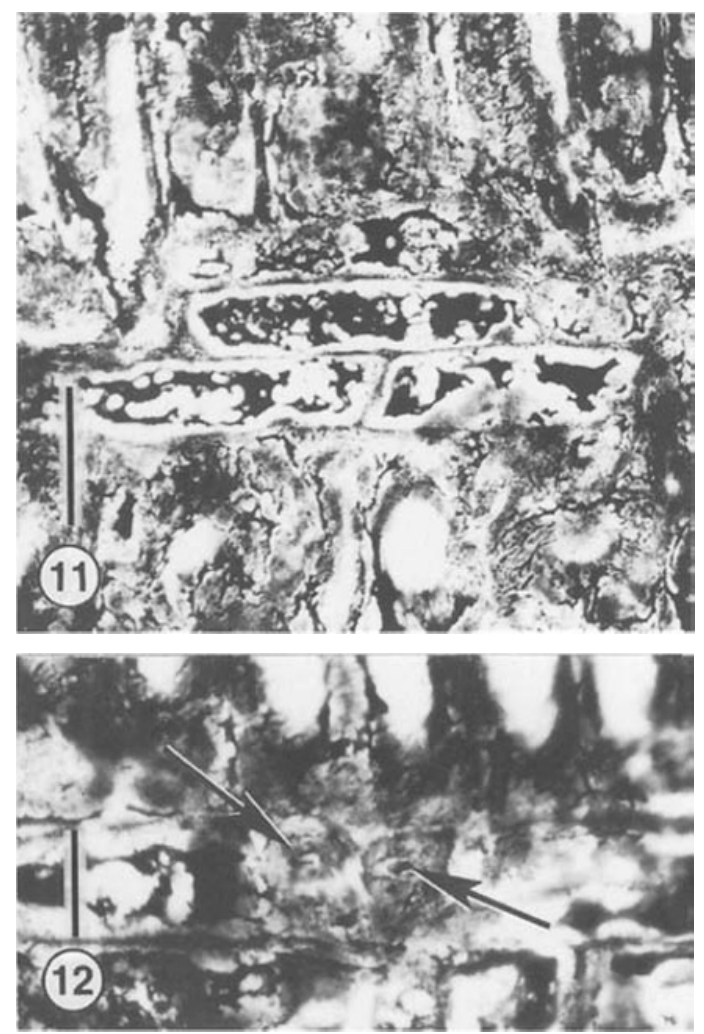
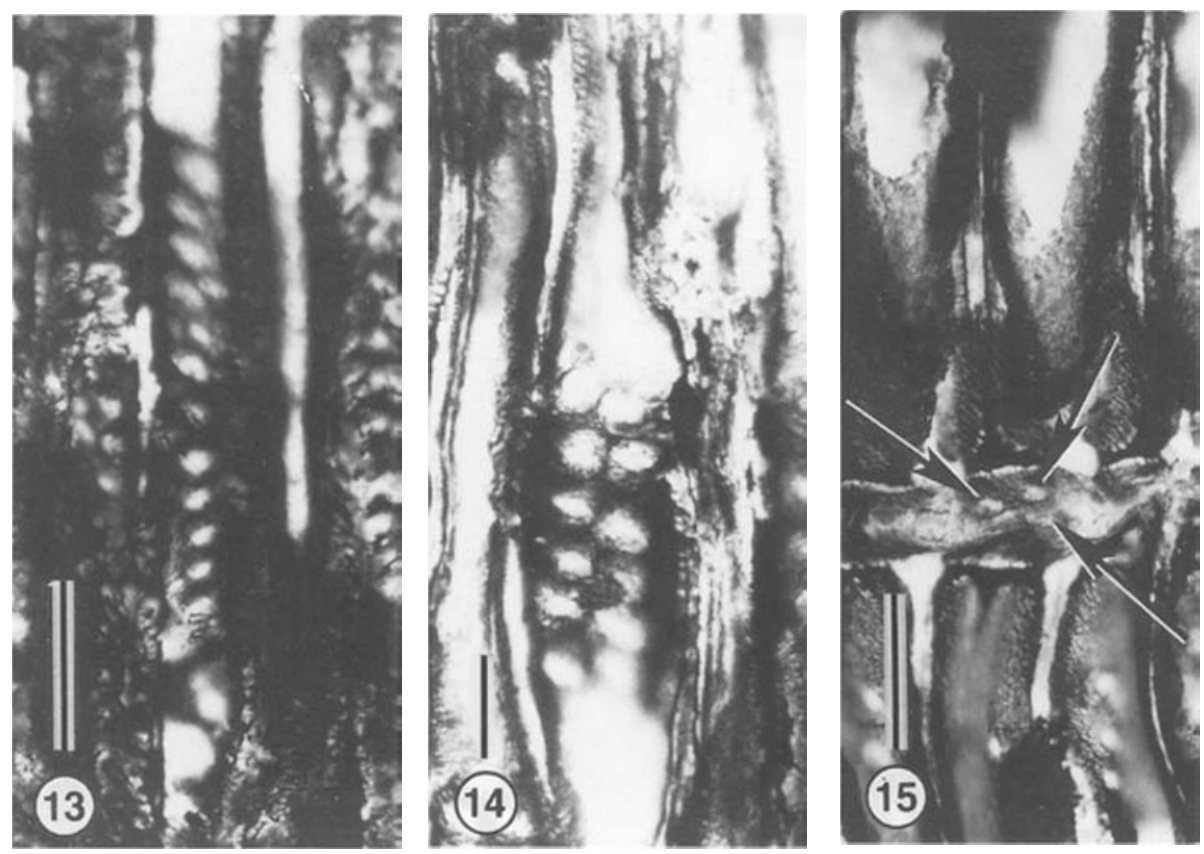
In areas where there is little crushing the rays are separated by $2-19$ rows of tracheids, with an average separation of 7 rows (Fig. 3). Tracheids are polygonal in transverse section (Fig. 6) and average $40 \mu \mathrm{m}$ in diameter; the wall is about $5 \mu \mathrm{m}$ thick. In Figure 7 the tracheid walls are separated from the middle lamella giving an elliptical shape to the tracheid. Axial parenchyma is not present.

Rays are uniseriate and from 1-9 cells high (Fig. 8). In tangential section, cells in the center of the ray are barrel-shaped, while those at the top and bottom are triangular with rounded corners. Each of the ray parenchyma cells is $25 \mu \mathrm{m}$ high and approximately $20 \mu \mathrm{m}$ wide. There are no pits on the tangential or transverse walls. In radial section the homocellular nature of the rays is obvious. Cells appear rectangular in outline and are up to $116 \mu \mathrm{m}$ long (Fig. 11). The majority (62\%) of the tangential walls show some degree of obliqueness. Many of the ray cells contain dark materials that tend to obscure wall features.

The length of the tracheids in Jeffersonioxylon is difficult to measure due to poor preservation, but some extend for more than $1200 \mu \mathrm{m}$. Individual elements are fusiform in outline, but some have slightly rounded ends (Fig. 10). Pits are confined to the radial walls and in most tracheids are uniseriate (Fig. 13), although in a few elements two rows are present and these appear to be oppositely arranged (Fig. 14). Pits are solitary and usually located toward the end of each cell. They are circular and approximately $10 \mu \mathrm{m}$ in diameter. The inner aperture is typically elliptical, but this is probably an artifact caused by distortion of circular apertures when the xylem was compacted. In tangential section, the bordered nature of the pits can be seen more clearly (Fig. 9). Cross-field pits in Jeffersonioxylon are difficult to characterize due to poor preservation. One or two pits per cross field are most common (Fig. 12), but a few sections contain 3 per cross field (Fig. 15). Cross-field pits are circular to oval and range from $3-5 \mu \mathrm{m}$ in diameter. All appear to be simple; however, preservation of these features is very poor.

\section{DISCUSSION}

The literature on Paleozoic and Mesozoic fossil gymnosperm wood is extensive and many species and genera have been established based on isolated specimens of secondary xylem. In Table 1, we have summarized selected species of Mesozoic gymnosperm woods from Gondwana, especially Antarctica. We have included those for which there is a reasonable amount of anatomical information available and in which overall preservation is relatively good, but have excluded types with centripetally developed wood (e.g., Kräusel 1956a, 1956b, 1962). Although Jeffersonioxylon gordonense is presently known only from features of the secondary xylem, we have included a few genera in Table 1 for which information is known about both primary and secondary tissues.

In contrast to the pith and primary tissues, the secondary xylem of many Paleozoic and Mesozoic gymnosperms, especially coniferous wood (e.g., Dadoxylon-type), is uniform and simply organized. Thus, there are relatively few meaningful characters 
that can be used to distinguish wood alone. Prasad (1982) noted that a parallel taxonomy exists for many fossil woods - one for those in which pith, primary and secondary xylem are present and one for those in which only secondary xylem is preserved. Lepekhina (1972) attempted to formalize this two-tiered taxonomic system and suggested that there are only 5 formal taxa that can be identified on the basis of secondary xylem alone: Araucarioxylon Kraus, Baieroxylon Greguss, Platyspiroxylon Greguss, Protophyllocladoxylon Kräusel, and Prototaxoxylon Kräusel \& Dolianiti. To these five taxa, Lepekhina (in Lepekhina \& Yatsenko-Khmelevsky 1966; Lepekhina 1972) added new names for just the secondary xylem fragments of taxa that had previously been described based on both secondary and primary xylem. Clearly, these artificial systems do nothing to improve our understanding of plant groups through time. Some authors however, such as Creber (1972), have recognized the importance of fossil wood in biostratigraphy and correlation, without contributing to the taxonomic problems outlined above. Others, such as Chapman and Smellie (1992), have chosen to use an artificial system. In this case, the authors described Cretaceous wood from the Antarctic peninsula using the Paleontologic Data-Handling Code system of Hughes (1989), resulting in taxa such as "Coniferwood-Cretaceous-clusteredpits." While this method does provide anatomical detail that can be useful to other investigators, in this case the wood is so well-preserved that it could have been assigned to existing fossil taxa. Thus, when one considers the diversity of this particular flora, it is difficult to understand exactly how many taxa are represented.

Most of the fossil woods that contain a pith and primary xylem are characterized by secondary xylem of the Dadoxylon-type. In this form, the tracheids have pits on the radial walls of the so-called araucarian or araucarioid-type, that is, they are multiseriate, alternate, and hexagonal. Together with Araucarioxylon, these two taxa are perhaps the most commonly used form genera for fossil wood and their taxonomy has been reviewed and emended several times (e.g., Maheshwari 1972; Giraud 1991; Philippe 1993). Seward (1919) regarded the two taxa as representing the same genus because of the difficulty in distinguishing them. Maheshwari (1972), on the other hand, suggested the taxa could be distinguished by the presence of uniseriate rays in Araucarioxylon and biseriate rays in Dadoxylon. Both taxa, however, exhibit araucarioid pitting. Since this pitting type does not occur in Jeffersonioxylon, the Antarctic wood cannot be assigned to one of these widely ranging form genera. Similarly, Kykloxylon Meyer-Berthaud et al., an anatomically preserved stem from the early Middle Triassic of Antarctica, can be eliminated from comparison since it also exhibits araucariantype pitting (Meyer-Berthaud et al. 1993).

Since Jeffersonioxylon and Antarcticoxylon Seward both occur in the Beacon Supergroup of Antarctica, it is important to discuss the features of these taxa. The intertracheal pitting in Antarcticoxylon consists of a single row of contiguous, slightly flattened pits, although some tracheids show two rows of alternate, polygonal pits (Seward 1914). Based on these features, Seward suggests affinities with the Araucariaceae. In contrast, the pits in Jeffersonioxylon generally occur in a single row and are circular; when biseriate, the pits appear opposite. In addition, the tracheid walls of 
Table 1. Select conifer woods from Gondwana.

\begin{tabular}{|c|c|c|c|c|c|}
\hline & Species \& Reference & $\begin{array}{l}\text { Age \& Locality } \\
\text { (Fm = Formation) }\end{array}$ & $\begin{array}{l}\text { Stem } \\
\text { diameter } \\
(\mathrm{cm})\end{array}$ & $\begin{array}{c}\text { Rays: } \\
\text { width / height } \\
\text { (\# of cells) }\end{array}$ & $\begin{array}{l}\text { Axial } \\
\text { paren- } \\
\text { chyma }\end{array}$ \\
\hline 1. & $\begin{array}{l}\text { Antarcticoxylon priestleyi } \\
\text { Seward } 1914\end{array}$ & $\begin{array}{l}\text { Upper Triassic } \\
\text { Fremouw Fm, Antarctica }\end{array}$ & 7.5 & $\begin{array}{l}\text { uni-/biseriate } \\
\quad(1-24)\end{array}$ & absent \\
\hline 2. & $\begin{array}{l}\text { Araucarioxylon floresii } \\
\text { Torres \& Lemoigne } 1989\end{array}$ & $\begin{array}{l}\text { Upper Cretaceous } \\
\text { Livingston Island, Antarctica }\end{array}$ & $?$ & $\begin{array}{l}\text { uniseriate } \\
(2-12)\end{array}$ & present \\
\hline 3. & $\begin{array}{l}\text { Cedroxylon neocaledonicum } \\
\text { Salard } 1968\end{array}$ & $\begin{array}{l}\text { Triassic } \\
\text { Marais de Mara, Nw Caledonia }\end{array}$ & $?$ & $\begin{array}{l}\text { uni-/biseriate } \\
\quad(1-20)\end{array}$ & present \\
\hline 4. & $\begin{array}{l}\text { Circoporoxylon amarjolense } \\
\text { Kräusel \& Jain } 1963\end{array}$ & $\begin{array}{l}\text { Jurassic } \\
\text { Rajmahal Stage, India }\end{array}$ & 1.5 & $\begin{array}{l}\text { uni-/biseriate } \\
\quad(1-15)\end{array}$ & absent \\
\hline 5. & $\begin{array}{l}\text { Cupressinoxylon nova-valesiae } \\
\text { Burges } 1935\end{array}$ & $\begin{array}{l}\text { Triassic } \\
\text { Hawkesbury Series, Australia }\end{array}$ & $5.5 \times 2.8$ & $\begin{array}{l}\text { uniseriate } \\
(2-8)\end{array}$ & present \\
\hline 6. & $\begin{array}{l}\text { Dadoxylon agathioides } \\
\text { Kräusel \& Jain } 1963\end{array}$ & $\begin{array}{l}\text { Jurassic } \\
\text { Rajmahal Series, India }\end{array}$ & 3 & $\begin{array}{l}\text { uni-/biseriate } \\
\qquad(2-20)\end{array}$ & absent \\
\hline 7. & $\begin{array}{l}\text { Kykloxylon fremouwensis } \\
\text { Meyer-Berthaud et al. } 1993\end{array}$ & $\begin{array}{l}\text { Middle Triassic } \\
\text { Fremouw Formation } \\
\text { Antarctica }\end{array}$ & 1.5 & $\begin{array}{l}\text { uniseriate } \\
(1-10)\end{array}$ & absent \\
\hline 8. & $\begin{array}{l}\text { Notophytum krauselii } \\
\text { Meyer-Berthaud \& Taylor } 1991\end{array}$ & $\begin{array}{l}\text { Middle Triassic } \\
\text { Fremouw Formation } \\
\text { Antarctica }\end{array}$ & $0.5-20$ & $\begin{array}{l}\text { uniseriate } \\
\quad(1-7)\end{array}$ & scanty \\
\hline 9. & $\begin{array}{l}\text { Podocarpoxylon indicum } \\
\text { Bhardwaj } 1953\end{array}$ & $\begin{array}{l}\text { Jurassic } \\
\text { Rajmahal Stage, India }\end{array}$ & 3 & $\begin{array}{l}\text { uniseriate } \\
\quad(1-5)\end{array}$ & absent \\
\hline 10. & $\begin{array}{l}\text { Podocarpoxylon walkomi } \\
\text { Kräusel } 1949\end{array}$ & $\begin{array}{l}\text { Jurassic } \\
\text { Walloon Series } \\
\text { Australia }\end{array}$ & 4 & $\begin{array}{l}\text { uniseriate } \\
(5-12)\end{array}$ & present \\
\hline 11. & $\begin{array}{l}\text { Protojuniperoxylon ischigualas- } \\
\text { tensis - Bonetti } 1966\end{array}$ & $\begin{array}{l}\text { Triassic } \\
\text { Ischigualasto Fm, Argentina }\end{array}$ & $?$ & $\begin{array}{l}\text { uni-/biseriate } \\
\quad(1--27)\end{array}$ & absent \\
\hline 12. & $\begin{array}{l}\text { Protophyllocladoxylon cort- } \\
\text { aderitaensis - Menéndez } 1956\end{array}$ & $\begin{array}{l}\text { Triassic } \\
\text { Cortaderita Beds, Argentina }\end{array}$ & 45 & $\begin{array}{l}\text { uniseriate } \\
(1-15)\end{array}$ & absent \\
\hline 13. & $\begin{array}{l}\text { Protopodocarpoxylon aff. guildense } \\
\text { Giraud \& Hankel } 1986\end{array}$ & $\begin{array}{l}\text { Jurassic } \\
\text { Nandanga Formation, Tanzania }\end{array}$ & $?$ & $\begin{array}{l}\text { uniseriate } \\
(1-15)\end{array}$ & absent \\
\hline 14. & $\begin{array}{l}\text { Protopodocarpoxylon triassicum } \\
\text { Kräusel } 1949\end{array}$ & $\begin{array}{l}\text { Triassic } \\
\text { Hawkesbury Series, Australia }\end{array}$ & $?$ & $\begin{array}{l}\text { uniseriate } \\
(3-10)\end{array}$ & scanty \\
\hline 15. & $\begin{array}{l}\text { Taxaceoxylon sp. cf. rajmahalense } \\
\text { Kräusel \& Jain } 1963\end{array}$ & $\begin{array}{l}\text { Jurassic } \\
\text { Rajmahal Stage, India }\end{array}$ & 2 & $\begin{array}{l}\text { uni-/biseriate } \\
\quad(1-22)\end{array}$ & absent \\
\hline 16. & $\begin{array}{l}\text { Xenoxylon canoasense } \\
\text { Kräusel } 1949\end{array}$ & $\begin{array}{l}\text { Middle Triassic } \\
\text { Canoas, Brazil }\end{array}$ & ? & $\begin{array}{l}\text { uni-/biseriate } \\
\qquad(2-7)\end{array}$ & ? \\
\hline 17. & Jeffersonioxylon gordonense & $\begin{array}{l}\text { Middle Triassic } \\
\text { Fremouw Fm, Antarctica }\end{array}$ & 45 & $\begin{array}{c}\text { uniseriate } \\
(1-9)\end{array}$ & absent \\
\hline
\end{tabular}


(Table 1 continued)

\begin{tabular}{|c|c|c|c|c|c|c|c|c|c|c|}
\hline & \multicolumn{3}{|c|}{ Tracheids in cross section } & \multicolumn{3}{|c|}{ Intertracheary pits } & \multicolumn{4}{|c|}{ Cross-field pits } \\
\hline & shape & $\begin{array}{l}\text { wall } \\
\text { thick } \\
(\mu \mathrm{m})\end{array}$ & $\begin{array}{l}\text { diam. } \\
(\mu \mathrm{m})\end{array}$ & shape & arrangement & $\begin{array}{l}\text { diam. } \\
(\mu \mathrm{m})\end{array}$ & $\begin{array}{l}\text { no./ } \\
\text { field }\end{array}$ & shape & $\begin{array}{l}\text { diam. } \\
(\mu \mathrm{m})\end{array}$ & $\begin{array}{l}\text { inner } \\
\text { aperture }\end{array}$ \\
\hline 1. & $?$ & $?$ & $?$ & $\begin{array}{c}\text { circular- } \\
\text { polygonal }\end{array}$ & $\begin{array}{l}1 \text { row flattened, } \\
2 \text { alternate }\end{array}$ & $?$ & $?$ & $?$ & $?$ & $?$ \\
\hline 2. & polygonal & $?$ & $18-60$ & $\begin{array}{c}\text { circular- } \\
\text { hexagonal }\end{array}$ & $\begin{array}{l}1 \text { row contigu- } \\
\text { ous, } 2 \text { alternate }\end{array}$ & $12-21$ & $1-4$ & circular & $10-15$ & $?$ \\
\hline 3. & polygonal & $?$ & $15-60$ & circular & $\begin{array}{l}1 \text { or } 2 \text { rows } \\
\text { opposite }\end{array}$ & $13-18$ & $2-6$ & $\begin{array}{l}\text { circular- } \\
\text { elliptical }\end{array}$ & $3.5-4$ & elliptical \\
\hline 4. & $\begin{array}{l}\text { square- } \\
\text { rectangular }\end{array}$ & $\begin{array}{l}? \\
?\end{array}$ & $\begin{array}{l}13 \times 20 \\
30 \times 20\end{array}$ & $\begin{array}{c}\text { circular- } \\
\text { oval }\end{array}$ & $\begin{array}{l}1 \text { row separate, } \\
2 \text { opp.-alternate }\end{array}$ & $\begin{array}{c}13 \\
16 \times 13\end{array}$ & $\begin{array}{l}1-2 \\
1-2\end{array}$ & circular & $5-7$ & simple \\
\hline 5. & polygonal & $?$ & $\begin{array}{l}20-30 \\
30-40\end{array}$ & circular & 1 row separate & $?$ & $2-4$ & $?$ & $?$ & $?$ \\
\hline 6. & polygonal & $?$ & $13-25$ & $\begin{array}{c}\text { circular- } \\
\text { hexagonal }\end{array}$ & $\begin{array}{l}1 \text { row flattened, } \\
2 \text { alternate }\end{array}$ & $\begin{array}{l}13 \times 10 \\
23 \times 13\end{array}$ & $\begin{array}{l}2-8 \\
2-8\end{array}$ & circular & 10 & elliptical \\
\hline 7. & $\begin{array}{l}\text { square- } \\
\text { polygonal }\end{array}$ & $?$ & $25-70$ & circular & $\begin{array}{l}1 \text { row separate- } \\
\text { contiguous, } \\
2 \text { opp.-alternate }\end{array}$ & $\begin{array}{c}8 \times 10 \\
10 \times 14\end{array}$ & $3-9$ & $\begin{array}{l}\text { oval- } \\
\text { circular }\end{array}$ & $\begin{array}{c}7 \times 10 \\
10 \times 25\end{array}$ & horizontal \\
\hline 8. & $\begin{array}{l}\text { square- } \\
\text { polygonal }\end{array}$ & $?$ & 50 & circular & $\begin{array}{l}1 \text { row separate- } \\
\text { contiguous, } \\
2 \text { opp.-alternate }\end{array}$ & $8-14$ & $1-4$ & $\begin{array}{c}\text { oval- } \\
\text { rectangular }\end{array}$ & $\begin{array}{c}7 x \\
10-24\end{array}$ & $\begin{array}{c}\text { horizontal } \\
\text { oblique }\end{array}$ \\
\hline 9. & $\begin{array}{l}\text { square- } \\
\text { polygonal }\end{array}$ & $?$ & $20-24$ & circular & 1 row & $10-12$ & I & oval & $?$ & elliptical \\
\hline 10. & $?$ & $?$ & $?$ & $\begin{array}{l}\text { circular- } \\
\text { elliptical }\end{array}$ & $\begin{array}{l}1 \text { row separate- } \\
\text { contiguous, } \\
2 \text { opposite }\end{array}$ & $?$ & $2-5$ & $?$ & $?$ & simple \\
\hline 11. & square & $2-7$ & $18-50$ & $\begin{array}{c}\text { circular- } \\
\text { hexagonal }\end{array}$ & $\begin{array}{l}1 \text { row contigu- } \\
\text { ous, } 2 \text { alternate }\end{array}$ & $15-18$ & $3-6$ & oval & $?$ & oblique \\
\hline 12. & $\begin{array}{l}\text { hexagonal- } \\
\text { rectangular }\end{array}$ & $?$ & $\begin{array}{l}33-37 \\
41-43\end{array}$ & $\begin{array}{c}\text { circular- } \\
\text { hexagonal }\end{array}$ & $\begin{array}{l}1 \text { row separate, } \\
2-3 \text { alternate }\end{array}$ & 16 & I & $\begin{array}{l}\text { circular- } \\
\text { oval }\end{array}$ & 23 & simple \\
\hline 13. & polygonal & $8-14$ & $\begin{array}{l}37-65 \\
56-73\end{array}$ & circular & $\begin{array}{l}1 \text { row separate, } \\
2 \text { alternate }\end{array}$ & $15-26$ & $2-10$ & $\begin{array}{l}\text { circular- } \\
\text { oval }\end{array}$ & $4-8$ & elliptical \\
\hline 14. & $?$ & $?$ & 30 & circular & 1 row & $?$ & $2-6$ & $?$ & $?$ & $?$ \\
\hline 15. & polygonal & $7-10$ & $13 \times 30$ & circular & 1 row separate & 10 & $?$ & $?$ & $?$ & $?$ \\
\hline 16. & $?$ & $?$ & $?$ & $\begin{array}{l}\text { circular- } \\
\text { elliptical }\end{array}$ & $\begin{array}{l}1 \text { row contigu- } \\
\text { ous, } 2 \text { alternate }\end{array}$ & $9-15$ & $1-8$ & circular & $?$ & simple \\
\hline 17. & polygonal & 5 & 40 & circular & $\begin{array}{c}1 \text { row separate, } \\
2 \text { opposite }\end{array}$ & 10 & $\begin{array}{c}1-2 \\
3\end{array}$ & $\begin{array}{l}\text { circular, } \\
\text { elliptical }\end{array}$ & $\begin{array}{c}5 \\
5 \times 3\end{array}$ & $?$ \\
\hline
\end{tabular}


Jeffersonioxylon are much thicker than those in Antarcticoxylon, but this may be an artifact of preservation. Although Walton (1925) included A. priestleyi in Rhexoxylon, this assignment is not generally accepted (Archangelsky \& Brett 1961). Meyer-Berthaud and Taylor (1991) re-examined Seward's material and also agreed that Antarcticoxylon should remain separate from Rhexoxylon. They note that although the genus is vaguely defined, the leaf trace emission (Seward's material was crushed) does appear to be similar to that in Notophytum Meyer-Berthaud \& Taylor (1991).

When all of the available characters are analyzed, Jeffersonioxylon appears most similar to wood included in the form genera erected for podocarpaceous wood types, such as Podocarpoxylon Gothan (Triassic-Tertiary), Mesembrioxylon Seward (JurassicRecent), and Circoporoxylon Kräusel. It also exhibits some similarities with Cupressinoxylon Göppert (Jurassic-Tertiary) (Table 1). Features in common include the abietinean nature of the pits (a single row of circular, separate pits or two rows of opposite, circular, and separate pits), the presence of low, uniseriate rays with unpitted cell walls, and circular to elliptical, simple cross-field pits that are few in number (Greguss 1955; Vaudois \& Privé 1971; Marguerier \& Woltz 1977). However, some of the most important features for distinguishing these wood taxa are characters of the cross-field pits, which are very poorly preserved in Jeffersonioxylon. For example, Boureau (1956) lists one of the principal differences between Podocarpoxylon and Cupressinoxylon as the orientation of the inner aperture of the cross-field pits; tending toward horizontal in Cupressinoxylon and oblique-vertical in Podocarpoxylon. However, this feature is not always constant. In the extant taxon, Podocarpus minor, the inner aperture is horizontal, while in extant Cupressus torulosa the aperture is vertical (Greguss 1955). Sahni (1931, 1938), in his study on Mesozoic conifer woods from India, mentioned this same problem in the fossil taxa, Podocarpoxylon and Cupressinoxylon. Overall, the cross-field pitting in Podocarpoxylon differs from that in Jeffersonioxylon in that the former has circular pits with very narrow, often slit-like apertures (podocarpoid type; Marguerier \& Woltz 1977), while the latter has simple circular pits.

Mesembrioxylon and Cupressinoxylon differ from Jeffersonioxylon in several features. Although Mesembrioxylon is poorly defined, Seward (1919) notes the presence of scattered axial parenchyma, while Sahni (1931) states it may be either present or absent. Both authors describe resin canals in wounded portions of the stem, a feature which does not occur in the Antarctic wood. Sahni (1931) cites Gothan (1905) as stating that neither resin canals nor axial parenchyma can be used to distinguish Mesembrioxylon from similar genera such as Cupressinoxylon. These authors believe the only important character is the nature of the cross-field pits. Like Cupressinoxylon (Vaudois \& Privé 1971), Mesembrioxylon can be distinguished from Jeffersonioxylon by the narrow, oblique aperture in the cross-field pits. Cupressinoxylon additionally differs from the Antarctic material in the abundance of axial parenchyma usually present in this taxon (Gothan 1905; Vaudois \& Privé 1971).

Circoporoxylon Kräusel is another form genus of fossil podocarp wood. This genus was very generally defined as secondary xylem with the anatomical features of a 
podocarp, but with circular cross-field pits (Kräusel 1949). One of the new combinations proposed by Kräusel was Circoporoxylon hortii Stopes (1915). Stopes' material, from the Lower Greensand of England (Cretaceous), is well-preserved and described as including uni-to multiseriate rays up to 80 cells high. The tracheids include pits on the tangential walls in the latewood. Rays are so numerous that they are often separated by only one row of tracheids. Although the genus is so broadly defined as to include almost all podocarp wood, the well-defined features of $C$. hortii suggest that Jeffersonioxylon cannot be allied with this taxon.

The presence of Notophytum Meyer-Berthaud \& Taylor, also from the Fremouw Formation in the central Transantarctic Mountains, is worth noting since this taxon shares several features with members of the Podocarpaceae (Meyer-Berthaud \& Taylor 1991). The genus is based on branching axes preserved in permineralized peat. Both primary and secondary xylem are preserved. The secondary xylem is similar in most respects to that of Jeffersonioxylon. However, the size and shape of the cross-field pits are different. Notophytum includes 1 to 2 or up to 4 pits per field. They are simple or slightly bordered and measure up to $24 \mu \mathrm{m}$ in diameter, much larger than those in Jeffersonioxylon, which do not exceed $5 \mu \mathrm{m}$ in diameter.

Considering all the characters available, Jeffersonioxylon has its closest affinities with members of the Podocarpaceae. However, in most cases the wood taxa associated with this family are either poorly defined, or Jeffersonioxylon does not contain crucial characters that would allow us to place it in an already existing taxon. In addition, because of the poor preservation of Jeffersonioxylon, the important characters of the cross-field pits are equivocal. Nevertheless, Jeffersonioxylon does provide additional evidence for the widespread distribution of the Podocarpaceae in Antarctica during the Mesozoic (Townrow 1967a, 1967b; Jefferson \& MacDonald 1981; Stockey 1989).

There have been attempts to characterize fossil wood types with little attention paid to natural affinities (e.g., Chapman \& Smellie 1992). However, we believe that such systems reduce the available information on fossil plants, since they provide no opportunity to investigate the evolutionary and biogeographic distribution of plant clades through time. Although the absence of a complete suite of anatomical characters in some fossil woods such as Jeffersonioxylon make assignment within major groups difficult, a detailed analysis of the preserved characters is the only method that can be used to establish character variability within major taxonomic groups. When combined with other sources of information (e. g., reproductive organs, pollen, other specimens that expand the character range) this increased resolution greatly expands the opportunity to more accurately define the distribution of conifer families like the Podocarpaceae in time and space.

\section{ACKNOWLEDGEMENTS}

This study was supported by funds from the National Science Foundation (OPP-9118314). We are indebted to Dr. Jochaim M. Schwuchow for his help in translating several papers. 


\section{REFERENCES}

Archangelsky, S. \& D.W. Brett. 1961. Studies on Triassic plants from Argentina. I. Rhexoxylon from the Ischigualasto Formation. Phil. Trans. Roy. Soc. London 244B: 1-19.

Barrett, P.J. \& D. H. Elliot. 1973. Reconnaissance geologic map of the Buckley Island Quadrangle, Transantarctic Mountains, Antarctica. Antarctic Geologic Map (U.S. Geol. Survey) A-3.

Barrett, P.J., D. F. Elliot \& D.H. Lindsay. 1986. The Beacon Supergroup (Devonian-Triassic) and Ferrar Group (Jurassic) in the Beardmore Glacier area, Antarctica. Ant. Res. Ser. 36 (14): $339-428$.

Bhardwaj, D.C. 1953. Jurassic woods from the Rajmahal Hills, Bihar. Palaeobotanist 2: 59-70.

Birnie, J.F. \& D.E. Roberts. 1986. Evidence of Tertiary forest in the Falkland Islands (Islas Malvinas). Palaeogeog., Palaeoclimatol., Palaeoecol. 55: 45-53.

Bonetti, M. 1966. Protojuniperoxylon ischigualastensis sp. nov. del Triásico de Ischigualasto (San Juan). Ameghiniana 4: 211-216.

Boureau, E. 1956. Anatomie Végétale, 2. Presses Universitaires de France, Paris, 524 pp.

Burges, N.A. 1935. Additions to our knowledge of the flora of the Narrabeen Stage of the Hawkesbury Series in New South Wales. Proc. Linn. Soc. New South Wales 60: 257-264.

Calder, M. G. 1953. A coniferous petrified forest in Patagonia. Bull. Brit. Mus. (Nat. Hist.) Geology 2: $99-138$.

Chapman, J.L. \& J.L. Smellie. 1992. Cretaceous fossil wood and palynomorphs from Williams Point, Livingston Island, Antarctic peninsula. Rev. Palaeobot. Palynol. 74: 163-192.

Conwentz, H. 1885. Sobre algunos árboles fósiles del Río Negro. Bol. Acad. Cien. Córdoba 7: $435-456$.

Creber, G. T. 1972. Gymnospermous wood from the Kimmeridgian of East Sutherland and from the Sandringham Sands of Norfolk. Palaeontology 15: 655-661.

Cúneo, N.R. 1991. Structural and paleoenvironmental analysis of the Jurassic Araucaria petrified forest from Patagonia, Argentina. Amer. J. Bot. 78 (6, Suppl.): 111.

Cúneo, N.R, J. Isbell, E.L. Taylor \& T. N. Taylor. 1993. The Glossopteris flora from Antarctica: Taphonomy and paleoecology. Comptes Rendus XII ICC-P 2: 13-40.

Cúneo, N.R., E.L. Taylor \& T.N. Taylor. 1991. Structure and ecology of Permian and Triassic petrified forests from the Transantarctic Mountains, Antarctica. Amer. J. Bot. 78: 111.

Douglas, G.V. 1923. Geological results of the Shackleton-Rowett (Quest) Expedition (lecture) (with comments by W.T. Gordon on fossil wood). Quart. J. Geol. Soc. London 79: x-xi.

Francis, J. E. 1986. Growth rings in Cretaceous and Tertiary wood from Antarctica and their palaeoclimatic implications. Palaeontology 29: 665-684.

Francis, J.E. \& M.F. Coffin. 1992. Cretaceous fossil wood from the Raggatt Basin, southern Kerguelen Plateau (Site 750). In: S.W. Wise, Jr., R. Schlich, et al. (eds), Proc. of the Ocean Drilling Program, Scientific Results, 120: 273-280.

Giraud, B. 1991. Les espèces du genre Dadoxylon depuis 1962: leur répartition et leur évolution du Permien à la fin du Mésozoïque. Rev. Palaeobot. Palynol. 67: 13-39.

Giraud, B. \& O. Hankel. 1986. Nouveaux bois fossiles de gymnospermes des dépôts du Karroo du Bassin du Luwegu (Tanzanie méridionale). Ann. Paléontol. (Vert.-Invert.) 72: 1-27.

Gordon, W. T. 1930. A note on Dadoxylon (Araucarioxylon) from the Bay of Isles. In: W.C. Smith (ed.), Report on the geological collections made during the voyage of the 'Quest' on the Shackleton-Rowett Expedition to the South Atlantic and Weddell Sea in 1921-1922: 24-27. British Museum (Nat. Hist.), London.

Gothan, W. 1905. Zur Anatomie lebender und fossiler Gymnospermen-Hölzer. Kön. Preuss. Geol. Landesanstalt u. Bergakademie (N.F.) 44: 1-108.

Gothan, W. 1908. Die fossilen Hölzer von der Seymour und Snow Hill-Insel. In: O. Nordenskyöld (ed.), Wissenschaftliche Ergebnisse der Schwedischen Südpolar-Expedition 1901-1903, 3 (8): $1-33$. 
Greguss, P. 1955. Identification of living gymnosperms on the basis of xylotomy. Akadémiai Kiadó, Budapest, 263 pp.

Grindley, G.W., V.R. McGregor \& R.I. Walcott. 1964. Outline of the geology of the NimrodBeardmore-Axel Heiberg Glaciers region, Ross Dependency. In: R. J. Adie (ed.), Antarctic Geology. Proc. 1st Intern. SCAR Symp. on Antarctic Geology, Cape Town, 1963: 206-219. North-Holland Publ. Co., Amsterdam.

Halle, T. G. 1912. The forest-bed of West Point Island. Bull. Geol. Inst. Univ. Uppsala 11 : 206218.

Hughes, N.F. 1989. Fossils as information. Cambridge University Press, Cambridge, 136 pp.

Jefferson, T. H. 1982. Fossil forest from the Lower Cretaceous of Alexander Island, Antarctica. Palaeontology 25: 681-708.

Jefferson, T.H. \& D.I. M. MacDonald. 1981. Fossil wood from South Georgia. Brit. Antarct. Surv. Bull. 54: 57-64.

Jefferson, T.H., M. A. Siders \& M.A. Haban. 1983. Jurassic trees engulfed by lavas of the Kirkpatrick Basalt Group, northern Victoria Land. Antarctic J. of the U.S. 18 (5): 14-16.

Kräusel, R. 1949. Die fossilen Koniferen-Hölzer (unter Ausschluss von Araucarioxylon Kraus). II. Kritische Untersuchungen zur Diagnostik lebender und fossiler Koniferen-Hölzer. Palaeontographica 89B: 83-203.

Kräusel, R. 1956a. Der 'Versteinerte Wald' im Kaokoveld, Südwest-Afrika. Senck. Leth. 37: 411-444.

Kräusel, R. 1956b. Hölzer aus dem südlichen Gebiet der Karru-Schichten Südwest-Afrika. Senck. Leth. 37: 447-453.

Kräusel, R. 1962. Antarctic fossil wood. Trans-Antarctic Expedition, 1955-1958, Sci. Rept. 9 (Geology): 133-154.

Kräusel, R. \& K.P. Jain. 1963. New fossil coniferous woods from the Rajmahal Hills, Bihar, India. Palaeobotanist 12: 59-67.

Lanteaume, M. 1950. Dadoxylon (Araucarioxylon) Boureaui n. sp., bois silicifié mésozoïque de Nouvelle-Calédonie. Bull. Soc. Géol. France 20: 33-38.

Lepekhina, V.G. 1972. Woods of Palaeozoic pycnoxylic gymnosperms with special reference to north Eurasia representatives. Palaeontographica 138B: 44-106.

Lepekhina, V.G. \& A. A. Yatsenko-Khmelevsky. 1966. Classification and nomenclature of woods of Palaeozoic pycnoxylic plants. Taxon 15: 66-70.

Loubière, A. 1938. Sur un bois triasique de Madagascar. Bull. du Muséum, $2^{e}$ sér., 10: 651-655.

Maheshwari, H. K. 1963. Studies in the Glossopteris flora of India: 16. Dadoxylon jamudhiense, a new species of fossil wood from the Raniganj Stage of Jharia coalfield, Bihar. Palaeobotanist 12: 267-269.

Maheshwari, H. K. 1972. Permian wood from Antarctica and revision of some Lower Gondwana wood taxa. Palaeontographica 138B: 1-43.

Marguerier, J. \& P. Woltz. 1977. Anatomie comparée et systématique des Podocarpus malgaches (1 ${ }^{\text {re }}$ partie). Adansonia, sér. 2, 17: 155-192.

Menéndez, C.A. 1956. Protophyllocladoxylon cortaderitaensis sp. nov. tronco fósil del Triásico de Barreal (Provincia de San Juan). Rev. Asoc. Geol. Argent. 11: 273-280.

Meyer-Berthaud, B. \& T.N. Taylor. 1991. A probable conifer with podocarpacean affinities from the Triassic of Antarctica. Rev. Palaeobot. Palynol. 67: 179-198.

Meyer-Berthaud, B., T.N. Taylor \& E.L. Taylor. 1993. Petrified stem bearing leaves from the Triassic of Antarctica. Palaeontology 36: 337-356.

Philippe, M. 1993. Nomenclature générique des trachéidoxyles fossiles mésozö̈ques à champs araucarioïdes. Taxon 42: 74-80.

Philippe, M., G. Barale, T. Torres \& V. Covacevich. 1993. First study of in situ fossil woods from the Upper Cretaceous of Livingston Island, South Shetland Islands, Antarctica: palaeoecological investigations. C. R. Acad. Sci, Série II 317: 130-108. 
Prasad, M.N.V. 1982. An annotated synopsis of Indian Palaeozoic gymnospermous woods. Rev. Palaeobot. Palynol. 38: 119-156.

Sahni, B. 1931. Revision of Indian fossil plants: Part 2. Coniferales (B. Petrifactions). Pal. Ind. 11:51-124.

Sahni, B. 1938. A Mesozoic coniferous wood (Mesembrioxylon shanense, sp. nov.) from the Southern Shan states of Burma. Rec. Geol. Surv. India 71: 380-388.

Salard, M. 1968. Contribution à la connaissance de la flore fossile de la Nouvelle-Calédonie. Palaeontographica 124B: 1-44.

Seward, A.C. 1914. Antarctic fossil plants. Brit. Antarct. Terra Nova Exped. (Genl ) 1: 1-49.

Seward, A.C. 1919. Fossil Plants. 4. Cambridge University Press, Cambridge.

Sharman, G. \& E.T. Newton. 1894. Note on some fossils from Seymour Island, in the Antarctic regions, obtained by Dr. Donald. Trans. Roy. Soc. Edinburgh 39: 707-709.

Sharman, G. \& E.T. Newton. 1898. Notes on some additional fossils collected at Seymour Island, Graham's Land, by Dr. Donald and Captain Larsen. Proc. Roy. Soc. Edinburgh 22: $58-61$.

Shirley, J. 1898. Additions to the fossil flora of Queensland, mainly from the Ipswich Formation, Trias-Jura system. Geol. Surv. of Queensland Bull. 7: 1-25, pl. 1-27.

Skinner, D. N. B. \& J. Ricker. 1968. The geology of the region between the Mawson and Priestley Glaciers, North Victoria Land, Antarctica. II. Upper Paleozoic to Quaternary geology. New Zeal. J. Geology \& Geophysics 11: 1041-1075.

Stockey, R. A. 1977. Reproductive biology of the Cerro Cuadrado (Jurassic) fossil conifers: Pararaucaria patagonica. Amer. J. Bot. 64: 733-744.

Stockey, R. A. 1989. Antarctic and Gondwana conifers. In: T. N. Taylor \& E.L. Taylor (eds), Antarctic Paleobiology, Its role in the reconstruction of Gondwana: 179-191. SpringerVerlag, New York.

Stopes, M.C. 1915. Catalogue of the Mesozoic plants in the British Museum (Natural History). The Cretaceous flora. Part II. Lower Greensand (Aptian) plants of Britain. British Museum (Nat. Hist.), London. $360 \mathrm{pp}, 32 \mathrm{pl}$.

Stopes, M.C. 1916. An early type of the Abietineae (?) from the Cretaceous of New Zealand. Ann. Bot. 30: 111-125.

Tasch, P. \& E.L. Gafford. 1984. Central Transantarctic Mountains nonmarine deposits. In: Geol. of the Central Transantarctic Mountains, Amer. Geophys. Union (Ant. Res. Ser.), Washington, D.C., 36 (5): 75-96.

Taylor, E.L., T.N. Taylor \& N.R. Cúneo. 1991. Permian and Triassic fossil forests from the central Transantarctic Mountains. Antarctic J. of the U.S. 26 (5): 23-24.

Taylor, E.L., T.N. Taylor \& N.R. Cúneo. 1992. The present is not the key to the past: A polar forest from the Permian of Antarctica. Science 257: 1675-1677.

Tessensohn, F. \& K. Mädler. 1987. Triassic plant fossils from North Victoria Land, Antarctica. Geol. Jahrb. 66B: 187-201.

Torres, T. \& Y. Lemoigne. 1989. Hallazgos de maderas fósiles de angiospermas y gimnospermas del Cretácico Superior en punta Williams, Isla Livingston, islas Shetland del Sur, Antártica. J. Inst. Antart. Chileno, Ser. Cient. 39: 9-29.

Townrow, J. 1967a. On a conifer from the Jurassic of East Antarctica. Proc. Roy. Soc. Tasmania 101: 103-136.

Townrow, J. 1967b. Fossil plants from the Allan and Carapace Nunataks, and from the upper Mill and Shackleton Glaciers, Antarctica. New Zeal. Geol. Geophys. 10: 456-473.

Vaudois, N. \& C. Privé. 1971. Révision des bois fossiles de Cupressaceae. Palaeontographica 134B: 61-86.

Walton, J. 1925. On some South African fossil woods. Ann. South African Mus. 22: 1-26.

Wieland, G. R. 1935. The Cerro Cuadrado petrified forest. Publ. Carnegie Inst. Washington 449: $1-171$. 